\title{
Theodore Abū Qurrah's debate at the Court of the Caliph al- Ma'mūn Reconsidered
}

\author{
Al-Amin Abouseda \\ Faculty of Arts - Tanta University
}

Egypt

Theodore Abū Qurrah was one of the well-known figures of the Christian Arab writers in the late eighth and early Ninth centuries. He was a bishop of the city of Harrān ${ }^{1}$, and was somehow related to the Monastery of Saint Saba in Jerusalem. He was also one of the few Arab Melkite Christians who were supposedly still mastering the Greek language and had more or less some ties with the Byzantine church and theology. ${ }^{2}$ His debate at the court of the Abbasid Caliph al-Ma'mūn (813-833 A.D./189-218 A.H.) is one of the earliest recorded religious debates between Christianity and Islam. Of this debate there are several and various surviving manuscripts; they amount to more than 30 different copies scattered between Europe and some private libraries in Syria. These copies of one single debate attracted several scholars, among them G. Graf, who undermined the authenticity of the debate. ${ }^{3}$ Meanwhile, other scholars such as I. Dick and A. Guillaume defended the genuineness of the text. ${ }^{4}$ At the same time both sides admitted the

1 A city near Edessa, though the same name used to refer to several other small villages around Aleppo, Yakūt al-Hamwī, Mu'diam al-Buldān, II, 235.

2 On Abū Qurrah see: J. C. Lamoreaux, "The Biography of Theodore Abū Qurrah Revisited", DOP 56(2002), 25-40; S. Griffith, The Controversial Theology of Theodore Abū Qurrah (c. 750-820 A.D.) a Methodological Comparative Study in Christian Arabic Literature, Ph.D. thesis; The Catholic University of America, Washington DC, 1978; Idem, “The view of Islam from the monasteries of Palestine in the Early Abbasid period: Theodore Abū Qurrah and the Summa Theologiae Arabica", ICMR 7 (1996) 9-28; A.-Th. Khoury, Les théologiens byzantins, 83-105;

D. Bertaina, An Arabic Account of Theodore Abū Qurrah in Debate at the Court of Caliph al-Ma'mun: a Study in Early Christian and Muslim Literary Dialogues, unpublished Ph.D. thesis, The Catholic University of America 2007, 195-200.

3 G. Graf, Geschichte der Christlichen Arabischen Literatur, II, 21-22. The same opinion held by R. Caspar et al. "Bibliographie du dialogue Islamo-Chrétien", Islamochristiana 1 (1975) 155.

4 I. Dick, Mugadalit abi Qurrah ma' al-Mutkalimīn al-Muslimīn fi Majlish al-Khalīfa al-Mam'mūn, introd. 37-40; A Guillaume, "Theodore Abū Qurra as apologist", Moslem World 15 (1925) 42- 51. 
striking differences between all the copies. ${ }^{5}$

One of the earliest copies of this debate has recently been the subject of a detailed discussion by David Bertaina in his Ph.D. thesis which is entitled: An Arabic Account of Theodore Abū Qurrah in Debate at the Court of Caliph al-Ma'mūn: a Study in Early Christian and Muslim Literary Dialogues. In his thesis Bertaina published, translated and commented on a manuscript of the dialogue attributed to Theodore Abū Qurrah at the court of the caliph al-Ma'mūn.

The manuscript, which Bertaina used in his study, is found in the Vatican Library under the name "Vatican Borg Arabic Ms", number 135 dated A.D. 1308. It bears some common features with several other dialogues, which appeared around the eighth and ninth centuries, such as the dialogue of al-Kindī and al-Hāshimī', ${ }^{6}$ the dialogue of John and 'Amr ibn al- ${ }^{\circ} \bar{A} a s,{ }^{7}$ and the letters exchanged between ${ }^{\circ}$ Umar b. 'Abd al- ${ }^{\circ}$ Azīz and the Byzantine emperor Leo III. ${ }^{8}$

These dialogues, it is important to note, were all written, copied and circulated within the Christian milieu. The balance of the two opponents' contributions usually tends to be on the side of the Christian interlocutor, who frequently has the upper hand, either in size of his answers, or in his intellectual appearance, or in his mastering of the debate. At the same time, most of these dialogues seem to be a kind of question and answer, sometimes a mere monologue, in which the

5 However, studying these manuscripts lies out of the scope of this paper, see: D. Bertaina, Theodore Abū Qurrah, 365-370.

6 Al-Kindī and Hāshimī, Risalat 'Abd Allah ibn 'Isma 'îl al-Hashimī 'ila 'Abd al-Masīḥ b. Ishāk al-Kind̄̄ yad'-hu biha 'ila al-Islām, wa risalat 'Abd al-Masīh ila alHashimì yaruddu biha 'alayhi wa yad'-hu ila al-Nașrāniyyah, (the message of 'Abd Allāh ibn 'Ismā'îl al-Hāshimī to 'Abd al-Masīḥ bin Isḥāḳ al-Kindī, in which he invites him to embrace Islam and the response of 'Abd al-Masīṇ, to al-Hāshimī, inviting him to embrace the Christianity) ed. Bible Lands Missions, Aid Society, London 1912.

7 M. F. Nau, "Un colloque du patriarche Jean avec l'émir des Agaréens", JS, IIe serie 5 (1915) 225-279. English trans. in: N.A. Newman (ed.) The early Christian-Muslim dialogue: a Collection of Documents from the First three Islamic Centuries (632900), translations with commentary, Hatfield, Pennsylvania, 1993, 7-47

8 M. Gaudeul, "The Correspondence between Leo and 'Umar: 'Umar's letter rediscovered", Islamochristiana 10 (1984) 109-157. 
Christian opponent also controlled fully the whole scene. ${ }^{9}$

Furthermore, almost all these texts have severe chronological problems: there are no specific dates, no known historical events, no well-known names, and if there are any, they are never found in any historical documents. Although this paper concentrates on Abū Qurrah's debate, it argues that this debate may in fact have constituted a model, which later dialogues have paralleled. ${ }^{10}$

The text of the debate, as edited by Bertaina, ${ }^{11}$ has some striking facts and several points, which need more attention. Prima facie, the text starts with a Christian expression "in the name of the Father, the Son and the Holy Spirit", which indicates undoubtedly that the writer, or the copier was Christian, and which also may imply that the readers were all Christians as well. ${ }^{12}$ This hypothesis is supported by the only historical narrative of the debate, in which the anonymous Syriac writer of thirteenth century, says, "the debate was written in a special book for anyone who wants to read it". ${ }^{13}$

The second and most striking fact is that the language of the whole text is very plain Arabic, far from the cultural revivals of the eighth and ninth centuries. Almost certainly, it could have hardly belonged to the first Abbasid era. There are several ambiguous, badly structured sentences. Throughout the whole text an enormous number of grammatical mistakes is scattered; most of which are even grave mistakes. The language itself seems nearer to modern colloquial

9 See for example the dialogue attributed to St. John of Damascus with unknown Muslim interlocutor. John of Damascus, Disceptatio Christiani et Saraceni. PG 94, cols.1585-98, Eng. trans. N. A. Newman, (ed.) The Early Christian-Muslim Dialogue: A Collection of Documents from the First three Islamic Centuries (6321$900 A D)$, translations with commentary, Interdisciplinary Biblical Research Institute, Hatfield, Pennsylvania, 1993, 144-152.

10 One may cite here the dialogue of the emperor Manuel II Paleologus with a certain Muslim scholar, which has similar circumstances with our dialogue here, as both were written and circulated within Christian milieu, while both dialogues supposedly occurred in Islamic lands. Manuel II Palaiologus, Dialoge mit einem Muslim, ed. with a parallel German trans. Karl Förstel, Oros Verlag, Altenberge 1993, Entretiens avec un Musulman, français trad. par A.-Th. Khoury, Paris 1966. 138-213.

11 I will follow here Bertaina's edition which is the editio princeps of the Manuscript.

12 D. Bertaina, Theodore Abü Qurrah, 225.

13 D. Bertaina, Theodore Abū Qurrah, 225. 
Egyptian. ${ }^{14}$ Furthermore, in analogy with other writings attributed to Abū Qurrah himself, our text seems far away different and prosaic. ${ }^{15}$

On the other hand, it is well-known from various Arabic sources that al-Ma'mūn was very eloquent in Arabic, and used to spot any mistake in the speeches or poetry of his courtiers, making sarcastic comments, sometimes erupted fully angrily at these mistakes which are called in Arabic laḥan لحن. He also had the ability to taste good poetry, and to memorize an enormous part of Arabic poetry, and the entire Quran. ${ }^{16}$ Furthermore, mastered jurisprudence and was capable of discussing complex legal matters with his judges ${ }^{17}$. As for the text under study his language is short, plain, simple, and is certainly far removed from cultural context of his reign. ${ }^{18}$

Nevertheless, in our text, the Muslim caliph, al-Ma'mūn is portrayed as a simple-minded person, destitute of knowledge and logic, and as someone who never utilized his holy book in the debate. He appears strangely less knowledgeable, poorly acquainted not only with the Christian dogma but also with the Quran, and Islamic doctrines, as he failed to notice 17 inaccurate quotations of the Quran out of total 21 used in this dialogue. There are, moreover, several sentences in the text, which explicitly illustrate his deep and unmistakable sympathy with the Christian interlocutor. He supported, protected, encouraged, and even admired Abū Qurrah for his refutation of all Muslim scholars in his court. Abu Qurrah on the other hand seems perilously bravado in his debate,

14 There are indeed several colloquial Egyptian words.

15 See for example, Abū Qurrah, Mayāmir Thawudūrus Abī Qurra usquf Harran, ed. K. al-Bashā, Beirut 1904; Idem, Maymar fì wujūd al-Khāiliq wa al-dīn al-qawìm, (Traité de l'existence du createur et de la vraie religion), ed. Ignace Dick, Bierut 1982.

16 Ibn al-Djawzī, Al-Muntaẓem, X, 52. On al-Ma'mūn generally see: Muḥammad Mușțafa Hadāra, Al-Ma'mūn al-Khalīfah al-'ālim, Cairo 1966.

17 Al-Ya'qubi, Tārīkh, vol. 2, Leiden 1883, 572.

18 Al-Ṭabrī, Tārīkh , 8, 657-658, narrates that one Arab poet went with a panegyric for al-Ma'mūn, and once he started to recite it, the caliph complete each verse, surprisingly with same words the poet created, and when the astonished poet said no one ever heard his poem before, the caliph told him that he added the poetry as it should be. 
mocking Muslim scholars in the presence of their caliph. ${ }^{19}$

Furthermore, the caliph was very delighted at the victory of Abū Qurrah, and shows his deep appreciation and joyfulness at Abū Qurrah's victory over Muslim scholars. Ironically, he even admired the eloquence of Abū Qurrah:

$$
\begin{aligned}
& \text { فلما سمع المأمون من أبو قرة ذلك أعجبه وفرح به غاية السرور بما سمع من }
\end{aligned}
$$

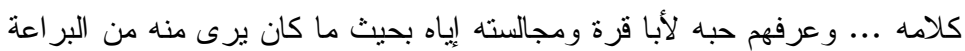

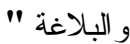

"When al-Ma'mūn heard that from Abū Qurra, he was astonished at it and was happy with it, quite delighted at what he heard of his discourse ... He showed to them his affection for Abū Qurra and his company because of what he had seen from him, based on his skill and eloquence" 20

In other version of the text the conclusion of the dialogue seems to be more exaggerated of al-Ma'mūn attitude at the end of the debate:

“Al-Ma'mūn said, 'How I wish that I had never seen this day, nor seen the failure of the Muslims and their lack of argument on behalf of their religion!'Then he ordered a robe of honour and annual gifts for Abū Qurrah, and made him his companion in the majlis" ${ }^{21}$

On the other side, al-Ma'mūn was depicted in extreme terms and as bizarrely tolerant in this dialogue, which alleged that the caliph accepted such severe refutation of the Muslim creed, sarcastic comments of Abū Qurrah, his wrong citations of the Muslim scripture and even

19 Compare with the very gracious and sincere language used by another Christian writer Qustā b. Lūqā (d. C. 912) in his polemical letter to a Muslim friend: "God knows, and sufficient is that He knoweth all, that I never said that trying to refute anyone, or wishing to weaken any strong faith and equable certitude. The strongest evidence for this, that I did not start or volunteer to do so but only after a request and strong insistence"

$$
\begin{aligned}
& \text { "وقد علم الله وكفي عليماً أنني ما قلت ذلك محاو لاً للطعن على أحد، ولا مُشتيها لإدخال الضعف على نية } \\
& \text { قوية ويقين مستو ، و أعظم دلائل على ذلك، أنني لا أفعل ذلك مبتدئا، و لا منبر عا، بل بعد مسألة و إلحاح شديد" }
\end{aligned}
$$

K. Samir et P. Nwyia, (eds.), Une correspondance Islamo-Chrétienne entre Ibn alMunăğğim, Hunayn Ibn Ishāq et Qusța ibn Lūqā, PO, 40, f. 4, N. 185, 682.

${ }^{20}$ D. Bertaina, Theodore Abū Qurrah, 439, 446 . Eng. trans. 395, 405.

21 M. N. Swanson, "The Christian al-Ma'mūn Tradition", in: D. Thomas (ed.), Christians at the Heart of Islamic Rule: Church Life and Scholarship in 'Abbasid Iraq, Leiden 2003, 66. 
encouraged Abū Qurrah to continue. While we should consider that he the very same caliph- persecuted several Muslim Scholars, such as Ahmad b. Hanbal, because of his dispute in the theological issue of creation of the Quran, in which the caliph showed no mercy or sympathy for those who do not accept his theological views regarding this issue.

In the same text of the debate there are four names of Muslim Scholars, who are supposed to be the elite of Muslim culture and religion who were chosen to defend Islam. Their names are: Abū Baker Muḥammad ibn 'Abd allah al-Hāshimī, Harūn ibn Hāshim al-Khuzāēi, Abū Bushara Sakan ibn Mu'āwyah al-Hamzānī, Șa 'șa ah ibn Khālid alBașri. $^{22}$ All four names, to be sure, are imaginary figures, (almost falsified) and invented by the writer himself or at best by a later copier. As expected, none of these names was found in any major Arabic biographical works or any other contemporary sources.

On the other side, like most of the similar polemical dialogues, there is an obvious consistent fixed tendency in the debate to select the Muslim supposed interlocutors and spectators from Qurayish, Prophet Muhammad's tribe, or at least to put them in very high positions, to be caliph or emir, or kāāin, or high cleric ${ }^{23}$. It is noteworthy that, in our dialogue here, one of the Muslim interlocutors bears the name Muḥammad ibn 'Abd allah al-Hāshimī, which is similar of the prophet name, most likely to make the coming victory look more impressive.

In his thesis, Bertaina said that "through the debate Theodore seeks to employ Quranic citations ... reveals a remarkable knowledge of individual suras", ${ }^{24}$ but Theodore indeed quoted twenty Quranic verses and appears to employ them cleverly in his polemic. But the overwhelming majority of these verses is totally incorrect and misses several words which certainly would not be accepted from all Muslim

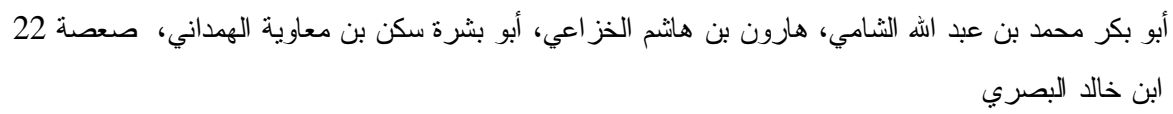

See on this point: Al-Bakrī, Muḥāwarat al-bațrīk Yūḥanā ma'a amīr al-'Arab, The dialogue between the patriarch John and the emir of the Arabs) Bulletin of the Faculty of Arts, Cairo University, 16/1 (May 1954) 23.

23 Such as the Caliph al-Mahdī, 'Amr ibn al-'Aās, and a certain Hashimī in the dialogue of al-Kindī.

24 D. Bertaina, Theodore Abū Qurrah, 327. 
scholars, as the following table shows:

\begin{tabular}{|c|c|c|c|}
\hline interlocutor & Quoted Quranic verses & correct & erroneous \\
\hline Muslim & 1 & - & 1 \\
\hline Abū Qurrah & 20 & 4 & 16 \\
\hline
\end{tabular}

Surprisingly, we found no objection from al-Ma'mūn and other scholars, who ipso facto must memorize their holy book ${ }^{25}$. It is worthwhile to note here that Muslim sources emphasize the fact that alMa'mūn was one of the few caliphs who memorized the whole Quran, and was one of the authorities of hadit (Sayings attributed to the Prophet). ${ }^{26}$

What undermines the authenticity of this text is the fact that almost all the contemporary Muslim texts, whatever their kind, polemical or political, usually depend heavily on the scriptural citations to support their views and logic. In our text here, we surprisingly find the Christian interlocutor who utilized Quranic quotations, albeit inaccurate ones, to support his view, while the Muslim side seems to be unqualified to use and utilize any verses from its book. Even among twenty-one quotations of the Quran they used only one, and surprisingly it was wrong.

At the same time, all the caliph's questions seem to be naïve and simple, and are more like questions of someone who wants to know about Christianity. Moreover, these questions do not show that they are being asked from a Moslem nor do they show any knowledge of Islam. The questions certainly have neither Islamic background nor scriptural quotations, strong motive or zeal to defend Islamic creed. ${ }^{27}$ To one of these questions asked by the caliph: "what do you say about foreskin? Is

25 It is noteworthy that, the only case allowed for any Muslim to interrupt a prayer either single or group (Djamā'ah) is to correct any wrong citation of Quran. 'Adel

Sa'd, Al-Ḍjāmi' li-aḥkām al-Ṣalāt wa-Ṣifat Șalāt al-nabiy, Beirut 2006, 172.

26 Ibn al-Djawzī, Al-Muntazem, X, 52..

27 This question and answer dialogue was known in Byzantium as erotapokresis,

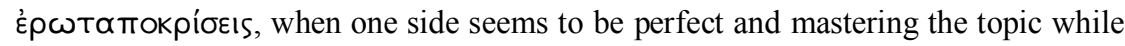
the other seems to be a mere student. See for example the very similar dialogue between Patriarch Nikephoros I and emperor Leo V. Alice-Mary Talbot, (ed.) Byzantine Defenders of Images, Eight Saints' Lives in English Translation, Dumbarton Oaks, Washington DC 1998, 83-99; ODB, I, 757, s.v. " erotapokresis". 
it unclean or not", ${ }^{28}$ Theodore argued that this part of human body had been created by God's hands and should not be unclean. In this case, the issue of foreskin's dirtiness is not the core of the Islamic doctrines concerning the circumcision. Furthermore, the Muslims scholar seems to be confounded and did not refer - as expected - to practice of Abraham (Ibrāhīm), or even to the fact that Jesus himself was circumcised. ${ }^{29}$

As for the polemical context of the dialogue, there are several allusions to traditional Christian critiques of Islam. However, it is out of the scope of this paper to discuss these allusions; what concerns us here is the way he employs these critiques, and that it seems to be extremely dangerous and that it is almost impossible to be applied in the court of a Muslim caliph. He furthermore says:

"While you hope for paradise by shedding blood, and your asking for God's acceptance to kill his creation ... and then being profligate with many women and your marrying divorced ones and your regarding them as permissible after your two friends (sic) married them. This is what God forbids and abhors" ${ }^{30}$

Again "as for your boasting and your expectation, when God did not create any part of it, are you no ashamed? Woe to you from God. AlMa'mūn asked him, "What is his Boasting. Abū Qurrah? Abū Qurrah responded to him ... his boasting about paradise and women with dark eyes". He said to him, "yes, it is thus" ${ }^{131}$

$$
\begin{aligned}
& \text { "قال له محمد يا أمير المؤمنين إن هذا رأيته غميقا ( هكذا) أصليا عتيقــا لا يمــل } \\
& \text { صاحبه من الكلام و لا يعيه رد الجواب. فأما دين الإسلام فقد تعلم أنه غطا (هكذا) }
\end{aligned}
$$

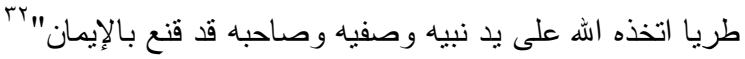

"Furthermore, "Muhammad said to him - al-Ma'mūn-, commander of the faithful, this religion is deep with ancient principles, its adherents

${ }^{28}$ D. Bertaina, Theodore Abū Qurrah, 434 (Arabic text), 388 (English translation) Bertaina translated (foreskin (ğalfa) as circumcision).

29 See the Dialogue of the Patriarch Timothy I and the Caliph al-Mahdī, in, Newman, N. A. Christian-Muslim Dialogue, 186, 209; the dialogue of al-Kindī, in: Idem, 470, 471

30 D. Bertaina, Theodore Abū Qurrah, 445 (Arabic text), 403 (English translation)

31 D. Bertaina, Theodore Abū Qurrah, 443 (Arabic text), 400 (English translation)

32 D. Bertaina, Theodore Abū Qurrah, 445 (Arabic text), 404-405 (English translation)

- Bertaina's translation of this sentence is not fully accurate. 
does not tire from speaking and he is never jaded by any answer. As for Islam, you know that it is a fresh green cover that God has brought through his Prophet and his chosen one. Its adherent has been content with faith"

The last quotation - which Bertain bypassed- makes a direct and sarcastic comparison between Christianity as a solid, and old religion, its adherent able to defend it, and Islam which is still seen as a new and fragile religion, its adherent صساحبه (here the reference to the Muslim interlocutor, or even to Prophet Muhammad himself) just content with faith, and able to defend it. This strange comparison was put into the mouth of a Muslim scholar as a confession to the caliph. It is difficult, almost impossible, that such an argument could have taken place in such a setting. There is no doubt that all these directed and sarcastic critiques of Islam would certainly cost Abū Qurrah his neck in such cases. ${ }^{33}$ Although there is no example in the reign of al-Ma'mūn for such punishment, one should bear in mind that the very same caliph did not hesitate to lash a leading Muslim scholar of his time for a theological dispute. $^{34}$

Strangely enough, a similar idea appeared in the Byzantine antiIslamic polemic, in a similar supposed dialogue between Byzantine ambassadors Constantine-Cyril with Muslim Scholars in the Court of the Caliph, in which there was a kind of sarcastic comparison between the deep sea of Christian faith and the shallow sea of Islamic doctrines. ${ }^{35}$

Like other similar dialogues, Abū Qurrah had the lion's share of the text. For every line of Muslim reply, we have at least 6-20 lines of Abū Qurrah's reply, which is similar to the famous dialogue of al-Kindī and al-Hashmī, as well as the in the letters attributed to 'Umar b. 'Abd al'Azīz and Byzantine emperor Leo III ${ }^{36}$

33 For example, a certain Melkiete monk called Michael the Sabaite had been executed after a supposed similar debate in the court of the Caliph 'Abd Malik ibn Marwān (685-705). S. Griffith, "The Monk in the Emir's Majlis: Reflections on a Popular Genre of Christian Literary Apologetics in Arabic in the Early Islamic Period", in: Lazarus-Yafeh, The Majlis," 21; A. Vasiliev, "The life of St. Theodore of Edessa", Byzantion 16 (1942-1943) 175.

34 Ahmad ibn Hanbal in the issue of the creation of the Qur'an.

35 F. Dvornik, "The embassies of Constantine-Cyril and Photius to the Arabs", VIII, in: Idem, Photian and Byzantine: Ecclesiastical studies, London 1974, 570.

36 In the letters attribute to 'Umar b. 'Abd al-'Azìz and Leo III, the Muslim letter is a few pages, while the Byzantine letter is at least ten times more; We can notice the 
In a word, the text of Abū Qurrah's debate with the caliph alMa'mūn is almost certainly fake. Although David Bertaina spent much time and hard efforts in his recent Ph.D. thesis to collect and compare the fragments of information from the current sources, ${ }^{37}$ the only source he found, which explicitly refers to the debate is the Anonymous Syriac Chronicle of 1234. Then he tried to link this debate with al-Tabrī narrative on al-Ma'mūn two raids on Byzantine lands in 214 and 215 A.H., and the narrative of Michael the Syrian who speaks on alMa'mūn's involvement in local Christian problems.

Reading the same sources again would undermine his hypothesis of the authenticity of the debate. al-Tabrī speaks on a village called "Qurrah" not Abū Qurrah, ${ }^{38}$ and there is no mention to any debate. Similarly Michael the Syrian did mention the Caliph's visit to Harrān, presented his favorable attitude towards Christian population, and his command to prevent the destruction of some churches there, but again there is no mention of Abū Qurrah, or any debates. ${ }^{39}$

Finally, we have three evidences for the date of the text: first, the oldest manuscript of the text, which is dated in 1308; second the anonymous Syriac source of 1234 which refers explicitly to the debate; and the third, an allusion to the debate in a Coptic liturgical encyclopedia - written in Arabic-of Abū al-Barakāt Ibn Kabar (d. 1324). Surprisingly what Ibn Kabar said, just only "he- Abū Qurrah- had known debates". Here there is no mention of al-Ma'mūn, or even to Muslims, so the debate concerned could have simply and equally occurred among different Christian sects, which was widely a common practice during this period. More importantly, Ibn Kabar listed Abū Qurrah among the Nestorians not Melkites, ${ }^{40}$ a fact that deeply undermines the accuracy of his narrative.

same balance in the letters of al-kindī and al-Hāshimī, as well as the dialogue attributed to 'Amr b. al- ${ }^{\circ}$ Aās and Patriarch John. The same was the dialogue of the emperor Leo V and Patriarch Nikephoros I.

37 D. Bertaina, Theodore Abü Qurrah, 230.

38 Al-Ṭabrī, Tärīkh, vol. 8, 623.

39 Michael the Syriac, III, 40 . (Arabic translation)

40 Miṣbāḥ al-Ẓulma fi 'Iḍāḥal-knhidma, Cairo 1971, 301; Cf. also, M. N. Swanson, The Christian al-Ma"mūn Tradition, 64- 65. 
Prima facie, all three previous evidences are Christians, and more important they are all too late more than four centuries after the date of the dialogue. But even if we accept the authority as Bertaina did, ${ }^{41}$ and if we agree that there was a real debate between the Muslim caliph and Abū Qurrah, it is almost certain that the current text of the debate is far from the original ones and that it must have been heavily edited and later interpolated to serve the Christian community. It must have undoubtedly undergone overtime many changes which are difficult to trace and to determine.

To sum up, the text was, to some extent, a catechetical tool for Christian readers, a moral support for young Christian laity in their daily life among Muslim communities, an apologetic guide for Christian theologians to face the increasing and mostly hostile Muslim polemic, and "presumably aimed at dissuading conversions to Islam among the Christians". ${ }^{42}$ The clearest evidence for this hypothesis is the narrative of a Syriac writer of thirteenth century, who said, "The debate was written in a special book for anyone who wants to read it". ${ }^{43}$

41D. Bertaina, Theodore Abū Qurrah, 262, note. 134. He argues that it could be "a commemoration of the historical debate, rather than of commemoration of the literary dialogue composed after the debate".

42 S. Griffith, The Monk in the Emir's Majlis, 13.

43 D. Bertaina, Theodore Abū Qurrah, 225. 
Abbreviations

\begin{tabular}{|l|l|}
\hline DOP & Dumbarton Oaks Papers \\
\hline et al & And others \\
\hline ICMR & Islam and Christian-Muslim relations \\
\hline JS & Journal Asiatique \\
\hline ODB & Oxford Dictionary of Byzantium \\
\hline PO & Patrologia Orientalis \\
\hline
\end{tabular}

Primary Sources:

Abū al-Barakāt Ibn Kabar, Miṣbāḥ al-Ẓulma fi 'Iḍ̂ạ̣ al-khidma, Cairo 1971.

Abū-Qurrah, Mugadalit abi Qurrah ma'a al-Mutkalimīn al-Muslimīn fì Madjlish al-Khalīfa al-Mam'mūn, ed, Igantius Dick (Halab 1999)

-------, Mayāmir Thawudūrus Abī Qurra usquf Ḥarrān, ed. K. al-Bashā, (Beirut 1904)

------, Maymar fì wujūd al-Khāliq wa al-dīn al-qawìm, (Traité de l'existence du createur et de la vraie religion), ed Ignace Dick (Beirut 1982). Texte Arabe.

Gaudeul M., 'The Correspondence between Leo and 'Umar: 'Umar's letter re-discovered' Islamochristiana, 10 (1984) pp. 109-157

Ibn al-Djawzī, al-Muntaẓem fi Tarīkh al-Mulūk wa al-Umam, ed. M. A. 'Atta, 19 vols. Beirut 1992.

John of Damascus, Liber de Haeresibus (ch. 101) PG 94, cols. 764-73. English translation, D. Sahas, John of Damascus; ed. with a German trans. Johannes Damaskenos und Theodore Abū Qurra, Schriften zum Islam, 74-83.

-----, Disceptatio Christiani et Saraceni. PG 94, cols.1585-97.

-----, Die Schriften des Johannes von Damaskos, ed. P. Bonifatius Kotter, 4 vols, (Berlin 1969-1981).

Al-Kindī and Hāshimī, Risalat 'Abd Allah ibn 'Isma 'ìl al-Hashimì ila 'Abd al-Masīḥ b. Ishậ̣al-Kindī yad 'hūu biha 'ila al-Islām, wa risālat 
'Abd al-Masīh 'ila al-Hashimī yaruddu biha 'alayhi wa yad 'hūu 'ila al-Nașrāniyyah, (the message of 'Abd Allāh ibn 'Ismā'îl al-Hāshimī to 'Abd al-Masīh ibn Isḥāk al-Kindī, in which he invites him to embrace Islam and the response of 'Abd al-Masịh, to al-Hāshimī, inviting him to embrace the Christianity) ed. Bible Lands Missions, Aid Society (London 1912)

Michael the Syriac, Tārîkh, trans. G. S. Sham'ūn, 3 vols. Damascus 1996.

Nau, M. F, 'Un colloque du patriarche Jean avec l'émir des Agaréens', $J S$, IIe serie 5 (1915) pp. 225-279. English trans. in: N. A. Newman (ed.) The early Christian-Muslim dialogue: a Collection of Documents from the First Three Islamic centuries (632-900), translations with commentary, (Hatfield, Pennsylvania, 1993) 7-47.

Samir, K. et P. Nwyia, (eds.), Une correspondance Islamo-Chrétienne entre Ibn al-Munağğim, Hunayn Ibn Isḥāq et Qusța ibn Lūqā, PO, 40, f. 4, N. 185, 682.

Al-Ṭabrī, Tarīkh al-Rusul wa al-Mulūk, ed. M. A. Ibarhīm, 11 vols., ed. 2, Cairo 1967.

Talbot, Alice-Mary, (ed.) Byzantine Defenders of Images, Eight Saints' Lives in English translation, (Dumbarton Oaks, Washington DC 1998)

Timothy I., L'église et L'Islam sous Timoythée I (780-823) étude sur l'église Nestorienne au temps des premiers 'Abbasides avec nouvelle édition et traduction du dialogue entre Timoythée et AlMahdi, ed. and trans. H. Butma (Beirut 1975) (Arabic text and French translation).

Yaḳūt al-Ḥamwī, Mu'djam al-Buldān, 5 vols. ( Beirut 1997)

\section{Modern Works:}

Al-Bakri, M. H., "Muḥāwarat al-bațīi Yūḥanā ma'a amīr al-'arab', (Dialogue between the Patriarch John and the Emir of the Arabs) Bulletins of the Faculty of Arts: Cairo University, 16/1 (May 1954) 23-45.

'Adel Sa'd, Al-Ḍjāmi' li-ạ̣kām al-Ṣalāt wa-șifat Șalāt al-Nabiy, Bierut 
2000.

Bertaina, D., An Arabic Account of Theodore Abū Qurrah Debate at the Court of Caliph al-Ma'mun: a Study in Early Christian and Muslim Literary Dialogues, unpublished Ph.D. thesis (The Catholic University of America 2007)

Caspar, R. et al., 'Bibliographie du dialogue Islamo-Chrétien', Islamochristiana 1 (1975) 125-181.

Dvornik, F., 'The embassies of Constantine-Cyril and Photius to the Arabs', VIII, in Idem, Photian and Byzantine: Ecclesiastical Studies, (London 1974).

Graf, G., Geschichte der Christlichen arabischen Literatur, Città del Vaticano, Biblioteca. Apostolica Vaticana, Studi e Testi, (19441953) 5 vols.

Griffith, S., The Controversial Theology of Theodore Abū Qurrah (c. 750-820 A.D.) a Methodological Comparative Study in Christian Arabic Literature, Ph.D. thesis; The Catholic University of America, (Washington DC, 1978).

------, 'The View of Islam from the Monasteries of Palestine in the Early Abbasid Period: Theodore Abü Qurrah and the Summa Theologiae Arabica', ICMR 7 (1996) 9-28.

------, 'The Monk in the Emir's Majlis: Reflections on a Popular Genre of Christian Literary Apologetics in Arabic in the Early Islamic Period', in: Lazarus-Yafeh, The Majlis, 13-65.

Guillaume, A., "Theodore Abū Qurra as apologist", Moslem World 15 (1925) 42- 51.

------, "A Debate between Christian and Moslem Doctors", Journal of the Royal Asiatic Society of Great Britain and Ireland, (Centenary supplement 1924) 233-244.

Hurst, T. R., The Syriac Letters of Timothy I (727-823): a Study in Christian-Muslims Controversy, unpublished Ph.D. thesis (The Catholic University of America 1986)

Lamoreaux, J. C., "The Biography of Theodore Abū Qurrah Revisited", DOP 56 (2002) 25-40

Lazarus-Yafeh, H. et al. (eds.), The Majlis: Interreligious Encounters in Medieval Islam (Studies in Arabic Language and Literature 4), (Wiesbaden 1999) 
Muḥammad Mușțafa Hadāra, al-Ma'mūn al-Khalīfah al-'ālim, Cairo, 1966.

Khoury, Adel-Théodore, Les théologiens byzantins et l'Islam: texts et auteurs VIIe-XIIe siècles. (Louvain-Paris 1969).

Vasiliev, A., 'The life of St. Theodore of Edessa', Byzantion 16 (19421943) $165-225$. 